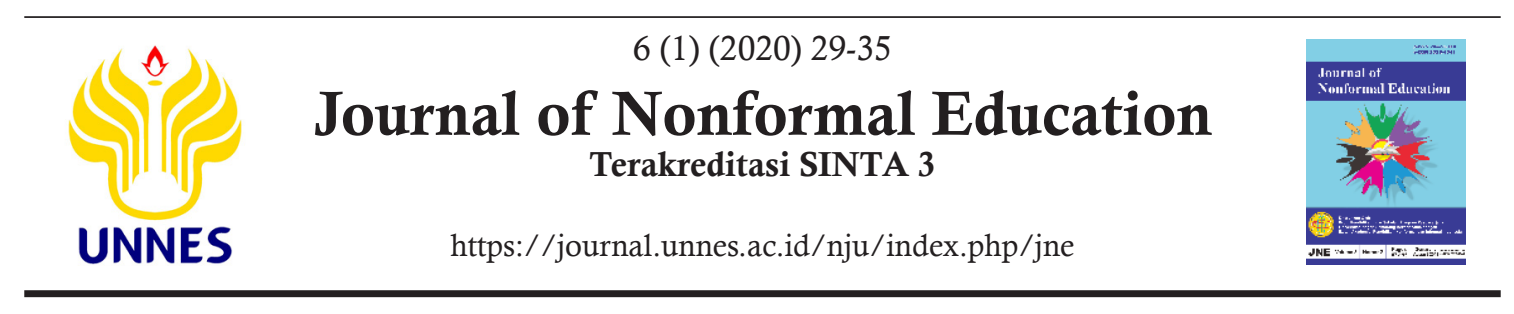

\title{
Songket Fabric Weaving Training in Empowering Poor Women at Home Industry
}

\author{
Mahrati Imaniar ${ }^{\bowtie}$, Joko Sutarto, Sungkowo Edy Mulyono
}

DOI: http://dx.doi.org/10.15294/jne.v6i1.20619

Universitas Negeri Semarang, Indonesia

\section{History Article}

Submitted 18 August 2019 Revised 24 January 2020 Accepted 4 February 2020

\section{Keywords}

training; empowerment poor women; songket weaving; home industry

\begin{abstract}
Songket fabric weaving training was conducted to empower poor women with the hope that they can overcome the family economy, acquire skills, and be able to become independent individuals. The objectives of this study were (a) to describe and analyze the program planning of songket fabric weaving training, (b) to describe and analyze the process of songket fabric weaving training, (c) to describe and analyze the success of songket fabric weaving training, (d) describe and analyze inhibiting and supporting factors in songket fabric weaving training. The approach used in this research was qualitative approach. The data were collected through observation, interviews, and documentation. The informants consisted of two tutors and three training participants. The results of this study show that (1) the training program planning was arranged according to the needs of the participants, (2) the training process was directed in accordance with the materials by employing adult learning methods, (3) the success of the training had different achievement standards, (4) internal and external factors became obstacles and supporters of songket fabric weaving training as competence of tutors, enthusiastic participants, assistance from non-governmental, market needs and lack of available tools. Weaving cloth training will be carried out with maximum if the trainer has the ability and spirit in learning. Andragogy learning methods are tailored to the needs of learners. In addition, support from the community in training support. In addition to the training, need to think about the market needs so that the training products can be sold to the community. The benefit of this research is as a reference in conducting the training should use andragogy in learning so that the training according to the needs of students and get results more effective and efficient.
\end{abstract}

Correspondence Author:

E-mail: mahrati94@gmail.com
p-ISSN 2442-532X

e-ISSN 2528-4541 


\section{INTRODUCTION}

Poverty alleviation as an issue of social justice and these women as bearers of human rights, in practice this approach places the responsibility for alleviating poverty squarely on the shoulders of poor women and girls (Mary Robinson, 2003). In the last half century, the movement for gender equality has faced setbacks in accomplishing its ultimate goal (Callahan, 2018). Women's poverty in Bima City is caused by several main factors such as low education, limited skills, and low economic level of the family (Yusrini, 2017). The average women who live in urban areas are those whose levels of education are only junior high school and senior high school. This is triggered by inadequate family economic factors to support the cost of education to a higher level.

Women's poverty is also caused by limited skills and low family economic background. Their limited skills have a quite serious impact which makes them more difficult to find a job, build a business, and utilize the natural resources in their region (Sartika et al., 2016). The low level of family economy also becomes one of the backgrounds of poverty experienced by women. They seem very difficult to meet the needs of life.

Difficulties in meeting the needs of life as said by (Cohen, 2014), it is stated that convolution of poverty and the loss of rights or wealth that is difficult to be returned is caused the insistence of needs that exceed the power threshold such as the expenditure that has been previously calculated, yet has a very large amount, or suddenly faced a great crisis. Those conditions drive a person into poverty. Poverty is related to several things including traditional obligations, physical disability, unproductive expenditure, and extortion (Banks, et al., 2017).

Based on the statements above, poverty is actually not something that is standard, but it is something that can be measured. According (Bhalla \& Lapeyre, 2004) and (Zulkifli, et al., 2019), it is stated that the level of poverty is considered based on certain norms that these chosen norms are very important, especially in terms of measuring poverty based on consumption. The consumption based poverty line consists of two elements (Hidayat \& Salman, 2018). Those are (1) expenditures needed to buy minimum nutritional standards and other basic needs, and (2) the number of other needs that varies greatly which reflects the cost of participation of daily life in the community. Thus capacity building can continue to grow and sustain in the future, in accordance with the increasing needs of the community itself
(Ansori, 2018).

In addition, one important factor that is often forgotten by the government in alleviating poverty in every region in Indonesia is feminine dynamic or gender inequality which states that poverty is closely related to the face of women as the main actors who experiecence the impact of poverty (Prasetyo, 2019). A family that lives below the poverty line reflects women who have always been the main pillars in saving the economic difficulties faced by the family. This is encouraged by several roles of poor women taken in the family, the role of women in the family includes: (1) as the one who control and manage family finance. (2) as the person in charge of all domestic works, (3) as a breadwinner (4) as one of the important nodes of social network in terms of social transfer, especially in critical times and crises (Marwati \& Astuti, 2012). Songket fabric weaving training is held to empower poor women to help them overcome the family economy, meet the needs of life and facilitate them to enjoy development acces in their region.

\section{METHODS}

This research applied qualitative approach. It is aimed so that the researcher can explain clearly and in detail the information or data obtained in their in-depth research on Songket fabric weaving training which started from program planning, implementation process, training success that occurs in the Raba Dompu Timur home industry in Bima City, West Nusa Tenggara Province, and the supporting factors and inhibitors of Songket fabric weaving training. The subjects in this study were two training tutors and three trainees. The training approach used in empowering the poor women was a group approach so that there were no boundaries between participants and trainers to interact in teaching and learning activities. There were two data sources in this study.

They were the main data obtained from observations in training planning programs including supporting infrastructure and environmental conditions. Related to the implementation of the training, it covered the process of learning activities, participants' responses, materials, methods, and providing motivation and communication between participants and tutors. Related to the evaluation of learning, it covered the type of songket fabric weaving evaluation. The interview done this study was to complete the data that cannot be revealed through observation. The researcher gave several questions directly to the 
manager, tutors and participants which refer to the focus of the problems.

The data collection techniques used were interviews, observation, and documentation including photos of the process of Songket fabric weaving training activities, vision and mission as well as works that had been successfully made by Nur Sakura home industry in implementing Songket fabric weaving training. The instruments used in this study were the researcher and other supporting tools such as notebooks, cameras, cellphones to record, and interview guidelines. To check the validity of the data in this study, source triangulation and method triangulation were applied. Source triangulation was done by comparing the information from different research subjects, while the method triangulation was done by obtaining data from observations, interviews, and documentation that would be investigated again. The data analysis techniques used were data reduction, data presentation and verification, or conclusion drawing.

\section{RESULTS AND DISCUSSION}

According to the research that has been conducted related to songket fabric weaving training, the results show that program planning conducted before the training began was arranged in accordance with the analysis of participant needs so that later the training activities can be on the right direction. The process of implementing learning activities was adjusted to the materials needed, while the approaches or the methods used were adjusted to the level of adult learning.

The evaluation process was carried out by the tutors to find out and measure the results of the training activities. If the participants feel the positive impact of Songket fabric weaving training, it can be said that the tutors have the competence that successfully bring changes and development of knowledge and skills of the participants. For the development of entrepreneurship programs requires awareness and readiness in understanding the potential then using it into an opportunity and strength to build a better quality of life (Karwati, et al., 2018).

Tutors must also have honest, disciplined, fair, patient and persistent attitudes in guiding so that they are able to carry out their duties properly and responsibly. In songket fabric weaving training there were some supporting and inhibiting factors for both internal and external inhibiting factors. The internal factors were the availability of tools and materials used were not proportional to the number of participants who registered, while the external factor was the lack of support from some local residents for the training activities. The supporting factors were the high enthusiasm, interest, and participation of the women to participate in the training activities.

According to (Sutarto, et al., 2017), learners in the learning system are the main components that act either as subjects or objects. It is considered as subjects because students are individuals who carry out the learning process and are expected to be able to achieve behavioral changes in them. This theory reinforces that without the students, learning process or songket woven fabric training will not run as expected because they are the subjects doing the learning process.

The researcher has obtained the results of the research. The songket fabric weaving training consisted of program planning, process of implementing activities, evaluating activities, success of activities and supporting factors and inhibiting training activities. Planning was carried out by managers and tutors to prepare material, media and methods used to facilitate the implementation of training activities so that the determined purposes can be achieved. The planning applied in songket fabric weaving training activities is the process of determining goals or objectives to be achieved and determining the path and sources to achieve goals as effectively and efficiently as possible (Marnisah \& Purnamasari, 2018).

To achieve the objectives as expected, the training activities must remain focused on the problems. This is in line with the theory stated by Bloom in (Wright et al., 2006) which distinguishes three main categories of training goal domains. These are (1) cognitive domains, that is the training objectives deal with increasing participant knowledge, (2) effective domain, that is the training objectives related to attitudes and behavior, (3) psychomotor, that is the training objectives related to the participants' skills. In addition, it is also in line with the statement from (Moon, 2009). I propose a model that links a change agent's self-awareness and reflexivity, his or her sensemaking of common sense perspectives related to planned change, and buy-in among organization stakeholders. The case is made for change agents to pay close attention to common sense perspectives because they can become the basis for particular problematic ambivalence and diminished change buy-in among stakeholders in the organization. This paper aims to address these issues. Design/methodology/approach - Conceptual and theoretical rationales for the model are offered. Examples from the psychological and organizational theory literatures provide support 
for the various elements of the model. Findings - Common sense perspectives should be factored into the diagnosis of the organization. Self-awareness, reflexivity, and sensemaking are all forms of social awareness that are necessary to engage stakeholders on matters of common sense. Research implications - Four research areas are identified. First, social and cultural contextual influences on common sense require clarification. Second, if resistance is multidimensional, how are dimensions influenced by common sense? Third, what group level of the organization (e.g., individual, group, organization which says that there are three main objectives that must be achieved with training. They are (1) meeting the needs of the organization, (2) obtaining a complete understanding and definition of work with standards and speed that has been determined and in normal and safe circumstances, and (3) assisting organizational leaders in doing their duties.

Yusnita et al. (2016) it is stated that the formulation of objectives in learning activities is very important for several reasons. Those reasons are to; (a) give direction to learning activities, (b) know the progress of learning and whether it is needed or not to provide remedial teaching for participants, and (c) use it as communication material. These theories are in line with the objectives of songket fabric weaving training, namely, to provide skills, be able to read business opportunities, increase knowledge and be able to become more independent, creative and innovative individuals.

The objectives that have been determined provide direction for learning activities and be able to know the learning progress of the participants in every practive they have done. The educational activities to develop target groups need to be done by organizing of the learning opportunities which support output applying quickly for example by providing business incubators, marketing training, and using technology which is relevant to success of the target group's business (Tohani, \& Prasetyo, 2019).

Songket fabric weaving training activities were done intentionally on the basis of planning made by managers and tutors with the hope of bringing changes for poor women (Stankard, 2010). In the framework of organizational development, training activities are carried out as an effort to improve organizational objectives. It means that the impact of training is expected to contribute to the quality of organizational services. The development process becomes the most important part as a determinant of the success of national development (Fakhruddin, 2019). In addition, training is the most specific educational message because it involves how to teach the community to do something (Copeland, 2016).

The success of the trainees is viewed from the number of behavioral changes. The success indicators of a program can be seen from the suitability of the process with what is planned, the suitability in achieving goals, the use and utilization of resources that is effective and efficient as well as the ability to provide guarantees for the suitability of the process and achievement of objectives through one harmonious and inherent control mechanis (Lewis, et al., 2011). Besides, to achieve a success, an approach is also needed in training activities of empowering women. In this case, the intended approach is to facilitate the community to be open between participants and tutors so that the activities carried out can achieve everyone's desired goals.

At the training implementation stages, there are things that need to be considered to achieve targets and objectives. At the training implementation stages, one of the things needed is a system approach in training. The approach used by the tutors was participatory andragogic. This approach was used because it is in accordance with adult learning methods and adult characters so that either participants or tutors do not have limits to interact with each other when training activities take place. This is in line with the theory stated by (Brockett \& Hiemstra, 2018) regarding the principles of adult learning that must be understood by professional educators, those are: self-direction learning, learning to know ways of learning, learning to evaluate themselves, the importance of feelings and free from threats. In addition, the theory of training above is in line with the statement (Rosid, et al., 2019) which states that training is as a system that covers three main stages, namely the assessment of training needs, implementation of training and evaluation of training.

The assessment of training needs is the most important stage in organizing training. This stage is used as a basis for the overall training efforts. Besides, the training needs must be examined as well as the resources available for training from both internal and external environment. To achieve a goal of the training, tutors must know the needs of trainees. Meeting the needs of the trainees must go through a need's analysis process. Needs analysis is an activity of searching, finding, recording, and processing the data about training needs that are desired or expected by the trainees in order to formulate training materials that are appropriate to the needs of the partici- 
pants (Sutarto, et al., 2018).

While the implementation of training is a learning process by delivering the material carried out by the facilitator and the trainees. The components applied in the implementation of the training include (1) training materials, (2) training approaches, methods, and techniques, (3) training assessment or evaluation, (4) training results (Kamil, 2012). The materials are things used in the training learning process. The materials provided or discussed must be in accordance with the interests and desires of the trainees. So, the material provided during the training learning process must be adjusted to the conditions and learning needs, interests and criteria of the the trainees. The principles of the formulation of training materials include (1) in accordance with the level of ability and background of the participants, (2) carefully selected and organized by considering aspects of benefits for participants, (3) must be beneficial for participants (Jannana \& Suryono, 2017).

The approach, method and training technique applied was a participatory andragogic approach. Andragogic model approach is an educational model for adults which is utilizing the experience of the trainees as a source of learning to be involved in planning, implementing and evaluating the training. Adult education should be chosen based on the educational objectives which can be divided into two, they are: (1) helping people organize their past experiences through new ways and helping individuals utilize what they know, (2) providing new knowledge or skills. The methods used in training implementation were individual and group systems. The techniques used in training were lectures, questions and answers, brainstorming, discussions, demonstrations, simulations, practices, and assignments (Ramli, et al., 2019).

At the evaluation stage, there are three stages that must be considered by the participants. Those are initial evaluation stage, process evaluation stage, and results evaluation stage. Greenfield, et al., (2013) states that aspects assessed in training evaluations are program components and program organizers including institutional, planning, implementation, coaching, economic efficiency and the impact of overall program. Whereas, according to (Mujiman, 2011) evaluation in training is an assessment of the success of a program. Training evaluation was carried out by the interviewees at the end of the training. It was integrated and monitored by the organizer. A comprehensive evaluation was carried out after the trainees attended the training.
The success of the training activity is felt when the participants have a positive impact during the activity. It can be said that the tutors have the competence to bring for the participants. This is supported by the existence of a competency test passing certificate and other certificates obtained by the tutors. Trainees who have been empowered through Songket woven fabric training have different successes in each participant. There are several factors that cause the differences in their success including hands that are still stiff because hand gestures in weaving tend to be slow so that the thread that is inserted in each strand is less tidy.

Sometimes the weaving tool can be broken at any time during the weaving process so that the woven fabric is less successful. In addition, other factors that can influence the success of participants in weaving songket fabrics are making motifs or patterns. The crossing threads between weft thread and warp threads sometimes reversed when crossed, and the use of additional threads on woven fabric. For trainees who just learn to weave, they need to be guided patiently and thoroughly when they are making patterns. For those who just learn, pattern making technique is the hardest part in weaving. In making songket pattern motifs, it usually takes two days to get the desired pattern or motif. So, at the time of participating songket fabric weaving training, the success of the participants in weaving fabric is still under the standard for some participants, while some others have reached the standard.

The inhibiting factor in weaving training is the lack of availability of tools so that it is not balanced with the participation of women which is relatively high. In addition, the availability of materials needed for weaving is not enough since the thread used can be broken so that it cannot be used for weaving and also the lack of support from some community members or family members. The factors that support songket weaving training activities are divided into internal factors and external factors. The supporting internal factors of Songket fabric weaving training include the desire, awareness and enthusiasm of the trainees to progress and develop such as high morale, and the courage of the participants to innovate. The working spirit of the trainees was very good, they were very eager to participate in the Songket fabric weaving training activities with a good enthusiasm for learning the training activities to achieve the expected goals. For supporting external factor is that in the form of tools and materials assistance from the local government or non-governmental institutions such as women's 
cooperative in Bima City, and the many market demands for songket woven fabric

\section{CONCLUSIONS}

Tutors or trainers plan and arrange the learning programs according to the needs to facilitate teaching and learning activities during the training process so that the learning system in songket weaving fabric can be well directed and achieve the expected goals. The trainees were given the materials in accordance to the need's analysis. The approach method applied should also be suitable for adults so that the training process can run well and achieve the expected goals. The trainees who participated in Songket weaving training at home industry achieved different successes with one another so that patience and accuracy in weaving are needed because it would affect the success rate in producing songket woven fabric. In songket weaving training, there are inhibiting factors and supporting activities. The inhibiting factors are the lack of the availability of equipment, the lack of participation of poor women who want to attend the training, the availability of materials that is not sufficient to support the needs of participants, the lack of support from some communities and family members of participants. The supporting factor is that the internal factor of awareness and desire of poor women to progress and develop is very high so that they are eager to participate in the training of songket fabric weaving. The external factor is the large market demand for songket woven fabric.

\section{REFERENCES}

Ansori, T. R. (2018). Increasing Economic Capacity of Rural Community Through The Use Of Local Ecological Potency Based. Journal of Environmental Protection, 4(1), 89-96.

Banks, L. M., Kuper, H., \& Polack, S. (2017). Poverty and disability in low- and middle-income countries: A systematic review. Plos One, 12(12), e0189996. https://doi.org/10.1371/journal.po ne.0189996.t003

Bhalla, A. S., \& Lapeyre, F. (2004). Poverty and Exclusion in a Global World. Heidelberg: Springer

Brockett, R. G., \& Hiemstra, R. (2018). Self-Direction in Adult Learning. London: Routledge

Callahan, I. (2018). Book Review: Gender in the Twenty-First Century: The Stalled Revolution and the Road to Equality Edited by Shannon N. Davis, Sarah Winslow, and David J. Maume. Gender \& Society, 32(4), 589-591. https:// doi.org/10.1177/0891243218757191

Cohen, M. G. (2014). Gendered Emissions: Counting Greenhouse Gas Emissions by Gender and
Why it Matters. Alternative Routes, 1(1), 55-80.

Copeland, T. J. (2016). Anthropology, Involve me and I learn: Teaching and a pplying. Annalsofanthropological Practice, 40(2), 120-133.

Fakhruddin, I. S. (2019). The Impact of Non-Formal Education in Community Development: A Case Study in Pati, Indonesia. International Journal of Innovation, Creativity and Change, 5(5), 339-352.

Greenfield, G. M., Keup, J. R., \& Gardner, J. N. (2013). Developing and sustaining successful firstyear programs: A guide for practitioners. John Wiley \& Sons.

Hidayat, T., \& Salman, R. (2018). Analisis Pola Pengeluaran Rumah Tangga Miskin di Kabupaten Simalungun. Jurnal Ekonomikawan, 24(2), 661670.

Jannana, N. S., \& Suryono, Y. (2017). Manajemen program short courses. Jurnal Akuntabilitas Manajemen Pendidikan, 5(1), 82. https://doi. org/10.21831/amp.v5i1.9795

Kamil, M. (2012). Model Pendidikan dan Pelatihan. Bandung: Aafabeta.

Karwati, L., Ansori, A., \& Mulyono, D. (2018). Women Empowerment to Build Entrepreneurship. Journal of Nonformal Education, 4(2), 169-176. https://doi.org/10.15294/jne.v4i2.16005

Lewis, L. L., Kim, Y. A., \& Ashby Bey, J. (2011). Teaching practices and strategies to involve inner-city parents at home and in the school. Teaching and Teacher Education, 27(1), 221-234. https://doi.org/10.1016/j.tate.2010.08.005

Marnisah, L., \& Purnamasari, E. D. (2018). Analisis peningkatan kualitas dan strategi pemasaran dalam rangka meningkatkan pendapatan perajin kain tenun songket di desa gunung batu kecamatan ogan komering ulu timur, Jurnal Abdimas Mandiri, 2(1), 30-35.

Marwati, S., \& Astuti, I. (2012). Model Pemberdayaan Perempuan Miskin Melalui Pengembangan Kewirausahaan Keluarga Menuju Ekonomi Kreatif di Kabupaten Karanganyar. Sepa, 9(1), 134-144.

Moon, M. Y. (2009). Making sense of common sense for change management buy-in. Management Decision (Vol. 47). https://doi. org/10.1108/00251740910946769

Mujiman, H. (2011). Manajemen Pelatihan Berbasis Belajar Mandiri. Yogyakarta: Pustaka Belajar.

Prasetyo, E. D. K. (2019). Faktor Kemiskinan dan Upaya Pemerintah Mengurangi Angka Kemiskinan. Retrieved from https://www.kompasiana.com/ emirdienulkukuhprasetyo/5dafb5e9097f36603 $12756 \mathrm{~d} 2$ /faktor-kemiskinan-dan-upaya-pemerintah-mengurangi-angka-kemiskinan?page=all

Ramli, I., Rusdiana, S., Basri, H., \& Munawar, A. A. (2019, June). Predicted Rainfall and discharge Using Vector Autoregressive Models in Water Resources Management in the High Hill Takengon. In IOP Conference Series: Earth and Environmental Science (Vol. 273, No. 1, p. 012009). IOP Publishing. 
Mahrati Imaniar et al. / Journal of Nonformal Education 6 (1) (2020) 29-35

Robinson, M. (2003). Poverty Reduction and Human Rights. Semarang: UNDIP.

Rosid, A., Sunarya, Y., \& Arifin, M. (2019). Teacher Training Scaffolding Type to Improve Teacherrs Ability in Developing Guided Inquiry Practical Worksheet. International Seminar on Language, Education, and Culture, 178-188. https://doi.org/10.18502/kss.v3i10.3900

Sartika, C., Balaka, M. Y., Rumbia, W. A., Jurusan, M., Ekonomi, I., Halu, U., ... Halu, U. (2016). Studi Faktor-Faktor Penyebab Kemiskinan Masyarakat Desa Lohia Kecamatan Lohia Kabupaten Muna. Jurnal Ekonomi, 1(1), 106-118. Retrieved from http://ojs.uho.ac.id/index. $\mathrm{php/JE/article/view/976}$

Sutarto, J., Mulyono, S. E., \& Raharjo, T. J. (2017, May). Design Of Training Based On Needs To Improve Pedagogic Competence Of The Tutors. In 1st Yogyakarta International Conference on Educational Management/Administration and Pedagogy (YICEMAP 2017). Atlantis Press. 66 (1), 102-107. https://doi.org/10.2991/yicemap-17.2017.17

Sutarto, J., Mulyono, S. E., Nurhalim, K., \& Pratiwi, H. (2018). Model Pemberdayaan Masyarakat Melalui Pelatihan Kecakapan Hidup Berbasis Keunggulan Lokal Desa Wisata Mandiri Wanurejo Borobudur Magelang. Jurnal Penelitian Pendidikan, 35(1), 27-40. https://doi. org/10.15294/jpp.v35i1.15091

Stankard, S. (2010). Textile Praxis: The Case for Malaysian Hand-Woven Songket Volume I Suzanne Stankard A Thesis Submitted in Partial Fulfilment Of the Requirements of the Royal College of Art For the
Degree of Doctor of Philosophy January 2010 The Royal College of Art.

Tohani, E., Prasetyo, I., \& Suharta, R. B. (2019). Women Empowerment in Disaster Vulnerable Village Through Vocational Life Skill Education Based on Utilization of Local Potential. Journal of Nonformal Education, 5(1), 35-46. https://doi.org/10.15294/jne.v5i1.18341

Wright, K. B., Bylund, C., Ware, J., Parker, P., Query, J. L., \& Baile, W. (2006). Medical Student Attitudes Toward Communication Skills Training and Knowledge of Appropriate ProviderPatient Communication: A Comparison of First-Year and Fourth-Year Medical Students. Medical Education Online, 11(1), 4594. https:// doi.org/10.3402/meo.v11i.4594

Yusnita, I., Masykur, R., \& Suherman. (2016). Modifikasi Model Pembelajaran Gerlach Dan Ely Melalui Integrasi Nilai-Nilai Keislaman Sebagai Upaya Meningkatkan Kemampuan Representasi Matematis. Jurnal Pendidikan Matematika, 7(1), 41-54.

Yusrini, B. A. (2017). Tenaga Kerja Wanita Dalam Perspektif Gender Di Nusa Tenggara Barat. Al-Maiyyah: Media Transformasi Gender Dalam Paradigma Sosial Keagamaan, 10(1), 115-131. https://doi.org/10.35905/almaiyyah.v10i1.4 52

Zulkifli, D., Suyasa, I. N., Maulita, M., \& Suharti, R. (2019). A conflict analysis of management of fishery resources in Kalimantan, Indonesia. International Journal of Fisheries and Aquatic Studies, 7(4), 78-85. 